\title{
AUTOMATIC DILUTION GAGING OF RAPIDLY VARYING FLOW
}

BY MARVIN D. DUERK

U.S. GEOLOGICAL SURVEY

Water Resources Investigations Report 83-4088

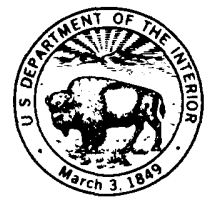

Madison, Wisconsin

October 1983 


\title{
UNITED STATES DEPARTMENT OF THE INTERIOR
}

JAMES G. WATT, SECRETARY

\section{GEOLOGICAL SURVEY}

\author{
Dallas L. Peck, Director
}

For additional information write to:

District Chief

U.S. Geological Survey, WRD

1815 University Avenue

Madison, Wisconsin 53705-4096
Copies of this report can be purchased from:

Open-File Services Section

Western Distribution Branch

U.S. Geological Survey

Box 25425, Federal Center

Denver, Colorado $\mathbf{8 0 2 2 5}$

(Telephone: (303) 234-5888) 


\section{CONTENTS}

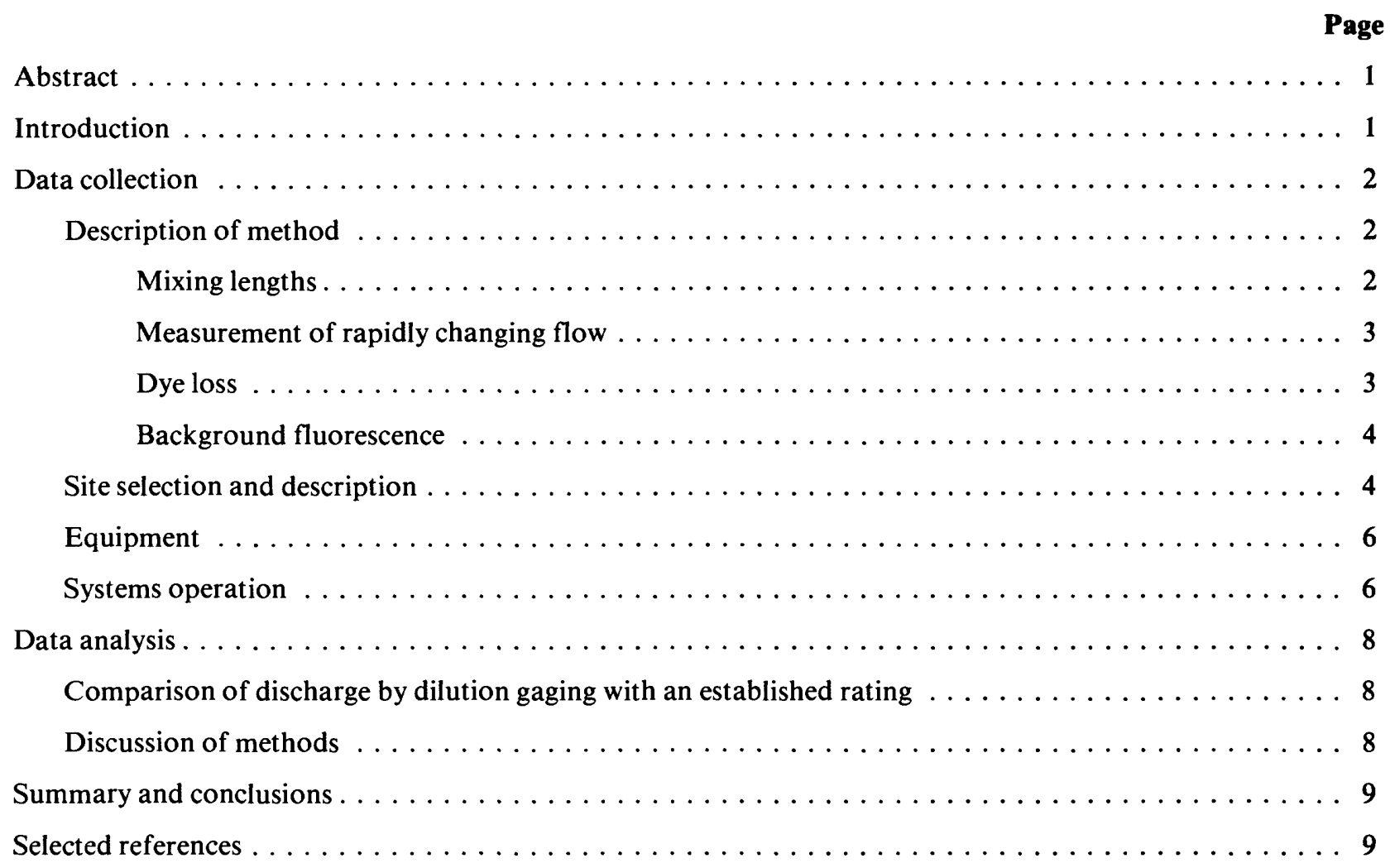




\section{ILLUSTRATIONS}

Page

Figure 1. Diagram showing injection and recovery systems . . . . . . . . . . . . . .

2. Graph showing concentration-time curve for constant-rate injection . . . . . . . . . . 3

3. Flow and dye concentration hydrographs for runoff event with

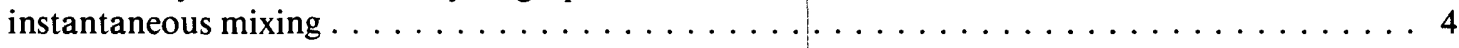

4. Map showing location of drainage basins and storm-sewer gaging stations

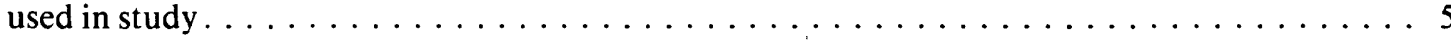

5-10. Hydrograph of:

5. Olbrich Park storm ditch for July 12, 1981, showing comparison of

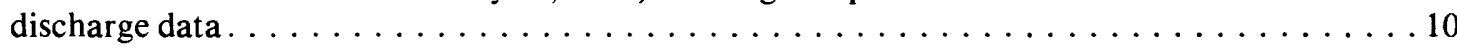

6. Olbrich Park storm ditch for August 14, 1981, showing comparison of

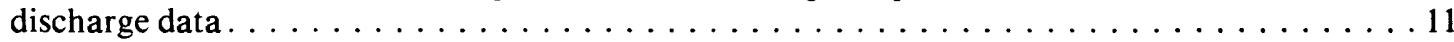

7. Olbrich Park storm ditch for August 31-September 1, 1981, showing

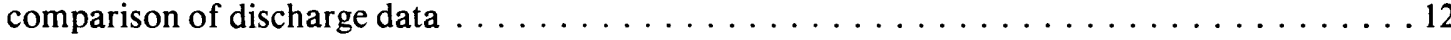

8. Manitou Way storm sewer for June 13, 1981, showing comparison of

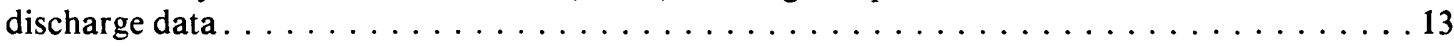

9. Manitou Way storm sewer for July 11, 1981, showing comparison of

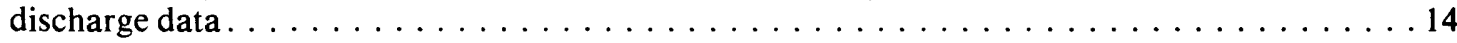

10. Manitou Way storm sewer for September 7, 1981, showing comparison of

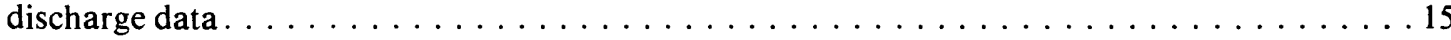

11. Graph showing comparison of dye-dilution measurements with rating curve

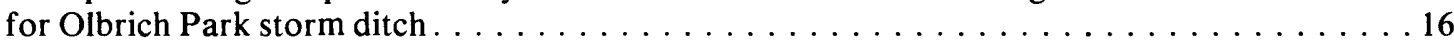

12. Graph showing comparison of dye-dilution measurements with rating curve for Manitou Way storm sewer. 
TABLES

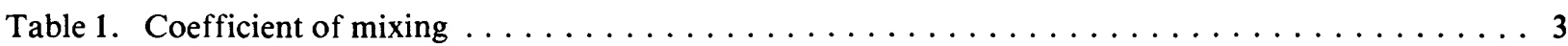

2. Comparison of peak discharges from dilution gaging to discharge from

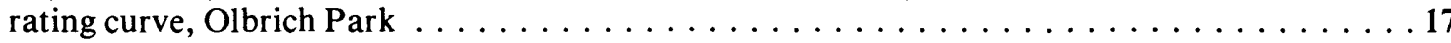

3. Comparison of peak discharge from dilution gaging to discharge from

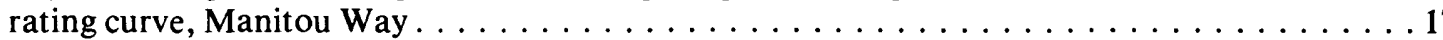

\section{FACTORS FOR CONVERTING INCH-POUND UNITS TO INTERNATIONAL SYSTEM OF UNITS (SI)}

For the convenience of readers who may want to use the International System of Units (SI), the data may be converted by using the following factors:

Multiply

inch (in)

foot (ft)

foot (ft)

foot per second $(\mathrm{ft} / \mathrm{s})$

mile (mi)

square mile $\left(\mathrm{mi}^{2}\right)$

cubic foot per second $\left(\mathrm{ft}^{3} / \mathrm{s}\right)$

pound (lb)
By

25.40

304.8

0.3048

0.3048

1.609

2.590

0.02832

453.6

\section{To obtain}

millimeter (mm)

millimeter (mm)

meter (m)

meter per second $(\mathrm{m} / \mathrm{s})$

kilometer (km)

square kilometer $\left(\mathrm{km}^{2}\right)$

cubic meter per second $\left(\mathrm{m}^{3} / \mathrm{s}\right)$

gram (g)

NOTE: Use or mention of a particular brand or model of equipment in this report does not imply a recommendation of its use by the U.S. Geological Survey. 


\title{
AUTOMATIC DILUTION GAGING OF RAPIDLY VARYING FLOW
}

\author{
BY MARVIN D. DUERK
}

\begin{abstract}
It is often difficult to obtain discharge ratings at urban gaging stations. This report presents the results of using an automated constant-rate dyedilution technique to measure discharge at two sites in Madison, Wisconsin. The sites selected have well-defined stage-discharge ratings, developed during previous hydrologic studies. One site has a 60-inch diameter concrete storm sewer and the other a concrete-lined open trapezoidal channel.

Equipment selected to automate the method included a portable automatic water sampler, a four-channel event recorder, and a variable-speed peristaltic pump for dye injection. An electrical switching circuit was designed to coordinate the operation of this equipment.

During the data-collection period of 1 year, a total of 20 storms were monitored.

The analysis showed that the discharges measured by dye-dilution techniques were generally within \pm 10 percent of the discharges determined from ratings established by current-meter measurements. Larger differences were noted at the start of and on the rising limb of four hydrographs. Of the 20 storms monitored, dilution measurements on 17 were of acceptable accuracy. Peak discharges from the open-channel site ranged from 0 to 12 percent departures from the existing rating whereas the comparison of peak discharge at the storm sewer site ranged from 0 to 5 percent departures from the existing rating.
\end{abstract}

\section{INTRODUCTION}

Discharge measurements are needed to rate conventional control structures or to calibrate flow meters in urban storm sewers. Obtaining discharge measurements is difficult at most urban sites using conventional methods. The principal difficulties are wide variations in duration and intensity of storms, inaccessibility, and the problems associated with measuring discharge during rapidly changing stage.

Dilution gaging is a well-established technique for measuring discharge in sewers and open channels where flows are steady and conditions permit manual injection and recovery (Cobb and Bailey, 1965, written commun.). The purpose of this report is to develop and evaluate a method to automate the constant-rate-injection technique, described by Cobb and Bailey, with sufficient accuracy and reliability to determine discharge in storm sewers under rapidly varying flow conditions. The report compares the results of obtaining discharges by dye dilution to that obtained from rating curves established by current meter measurements. Two urban gaging stations that have well-defined independently determined stage-discharge relationships were selected to evaluate the automatic dilution gaging equipment. 


\section{DATA COLLECTION}

\section{Description of Method}

The constant-rate-injection method was used to apply the dilution technique for this study. Of the several methods it is the most accurate for unsteady flow, least expensive, and requires the least amount of effort. Furthermore, it was the intent to measure the entire flow hydrograph through a runoff event by injecting tracer throughout the duration of such an event; hence the requirement for a continuous constant-rate injection. Measurement of discharge by the constant-rate-injection method depends on accurately determining the degree of dilution of a tracer solution injected into the flow at a constant rate and sampled downstream after complete, or nearly complete, mixing has occurred. For steady flow, discharge can be computed using the following equation (Kilpatrick, 1968).

$$
\mathrm{Q}=\mathrm{Kq} \mathrm{C}_{1} / \mathrm{C}_{2}
$$

where:

$\mathrm{Q}=$ stream discharge in cubic feet per second;

$C_{1}=$ concentration of the injected tracer solution; mixing;

$\mathrm{C}_{2}=$ concentration of tracer downstream after

$\mathrm{q}=$ injection rate in milliliters per second; and

$\mathrm{K}=\mathrm{a}$ constant of $3.53 \times 10^{-5}$ when $\mathrm{q}$ is in milliliters per second and $Q$ is in cubic feet per second.

Dyes, inorganic salts, and radioisotopes have all been used successfully as tracers. Fluorescent dyes and fluorometers that can detect their presence in very low concentrations $(<1.0 \mu \mathrm{g} / \mathrm{L})$ make dye a very practical and useful way to measure discharge by dilution. For this study, rhodamine-WT, 20 percent dye, was chosen as the tracer and is, at the present, the fluorescent dye commonly used by the U.S. Geological Survey (USGS) for tracer work (Hubbard and others, 1982).

The constant-rate-injection method used in this study utilizes an injection system and a recovery system (fig. 1). The injection system uses an injec-
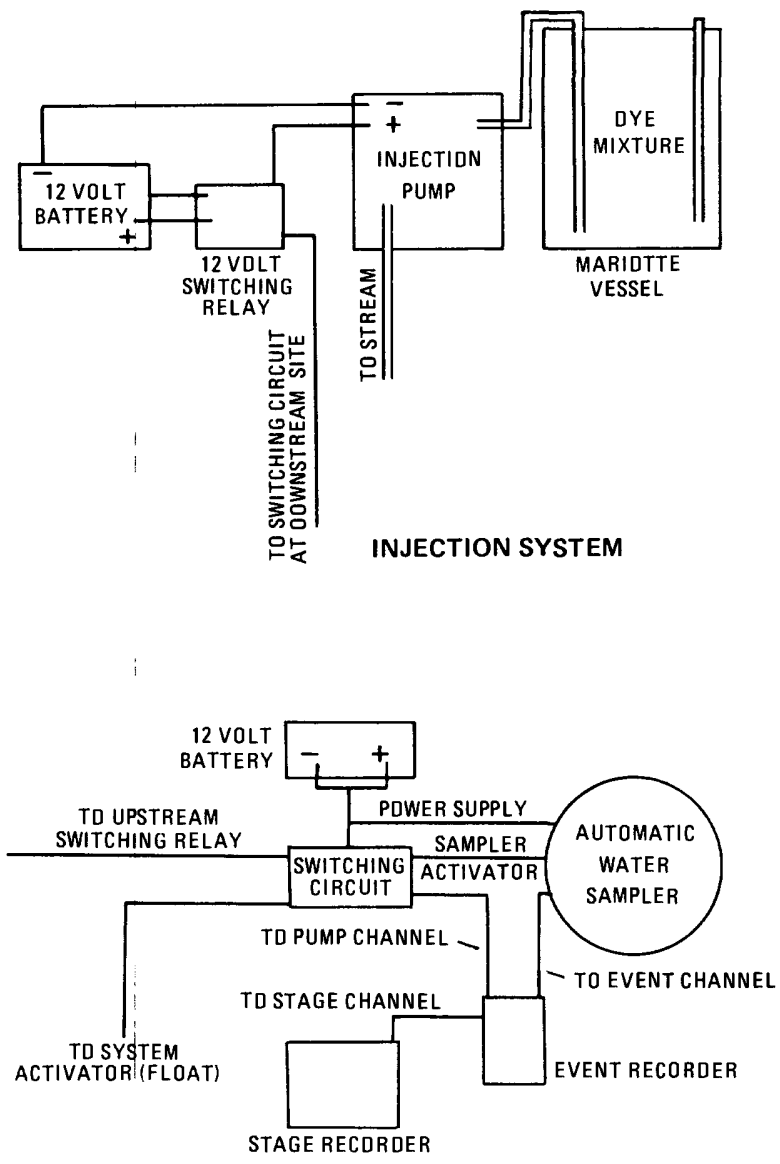

RECOVERY SYSTEM

Figure 1. Diagram showing injection and recovery system.

tion pump and a reservoir located at an appropriate mixing distance upstream from the sampling point. The recovery system consists of an automatic water sampler with the intake located in the measurement section. The recovery system also consists of a multichannel event recorder installed with a stage recorder to correlate individual dye samples with the stage recorded at the gage (fig. 1).

\section{Mixing Lengths}

Measurement of discharge by dilution requires the tracer to be at least 98 percent mixed, as defined by Yotsukura and Cobb (p. C6, 1972), at the sampling point. Less than this may be tolerated when physical conditions will not allow adequate mixing, or when flows are changing rapidly and 
when special sampling techniques are used. The potential for error due to unsteadiness becomes greater as the mixing length is increased. Therefore, it may be necessary to accept less than 98 percent mixing at times, but anything less than 95 percent would probably not produce acceptable results without special sampling.

Multiple injection is probably the most effective way to reduce mixing lengths. The following equation used in conjunction with table 1 below (Kilpatrick, 1981, written commun.) gives a good approximation of the length of channel necessary for different degrees of mixing when different numbers of point injections are used. From this it can be seen that if two injection points are used, the mixing length required is one fourth of that for a single point. For a three-point injection, the mixing length is only one ninth of that for a single-point injection. Additional mixing length information may be found in Hubbard and others (1982) and Yotsukura and Cobb (1972).

$$
\mathrm{L}_{\mathrm{m}}=\mathrm{KV} \mathrm{W}^{2} / \mathrm{D}
$$

where:

$$
\begin{aligned}
& \mathrm{L}_{\mathrm{m}}=\text { mixing length, in feet; } \\
& \mathrm{V}=\text { mean velocity, in feet per second; } \\
& \mathrm{W}=\text { average channel width, in feet; } \\
& \mathrm{D}=\text { mean depth, in feet; and } \\
& \mathrm{K}=\text { coefficient of mixing. }
\end{aligned}
$$

\section{Measurement of Rapidly Changing Flow}

In theory, the constant-rate injection method of dilution gaging requires that flow remain steady. In the case of steady flow, a tracer is injected into the flow long enough to produce a concentration plateau, $\mathrm{C}_{2}$ in equation (1), at the sampling point as shown by figure 2 . In practice, storm runoff such as experienced in urban systems produces rapidly changing flows. If no mixing reach were required, tracer concentrations would decrease proportionally as discharges increase as shown in figure 3. Several papers have been written addressing the problem (Gilman, 1975, 1977). Most agree that some degree of unsteadiness of flow can be tolerated; the degree has been partially answered by these tests. Most errors are likely to occur at the start and during the rising limb of a storm hydrograph. Most success will be achieved near the peak and on the recession limb providing the time to peak is somewhat longer than the mean traveltime in the mixing reach.

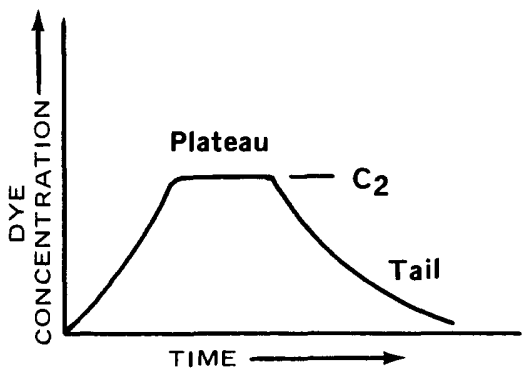

Figure 2. Concentration-time curve for constant-rate injection.

\section{Dye Loss}

Table 1. Coefficient of mixing.

\begin{tabular}{cccc} 
Percent & \multicolumn{4}{c}{ Number of injection points } \\
mixing & $\mathbf{1}$ & $\mathbf{2}$ & $\mathbf{3}$ \\
90 & 1.05 & 0.26 & 0.12 \\
95 & 1.5 & .38 & .17 \\
98 & 2.1 & .53 & .23
\end{tabular}

No tracer is totally conservative; when rhodamine-WT is used as a tracer, it is possible to have dye losses on suspended sediments and on sampling equipment. By examining the discharge equation (1), it can be seen that if dye losses are significant, discharge computed by dilution will be greater than the actual value. In this study, dye losses in the streamflow did not seem to be a problem, but it is likely that it would become a problem in flows that contain high concentrations of clay-size sediments (Scott and others, 1969). 


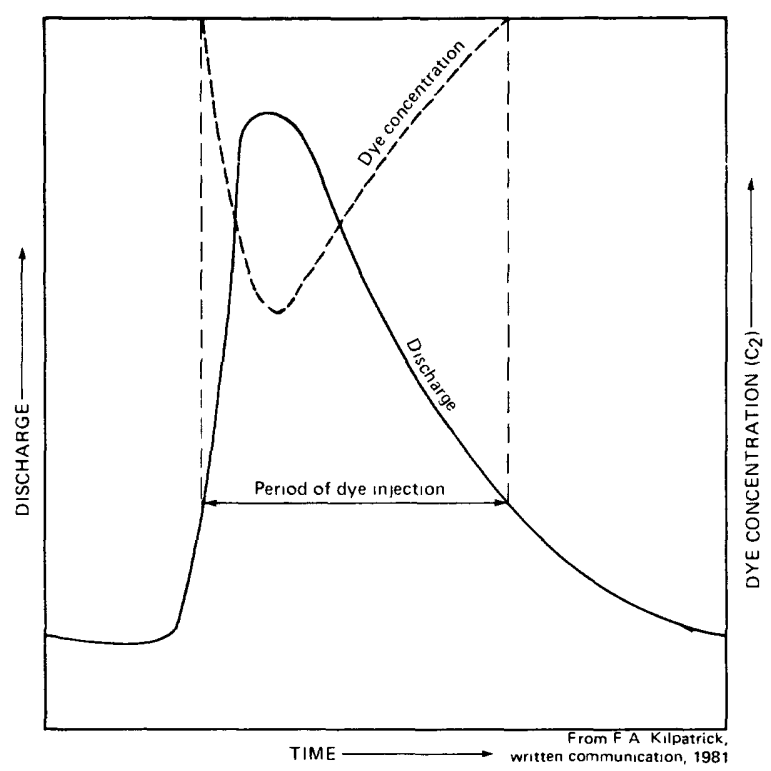

Figure 3. Flow and dye concentration hydrographs for runoff event with instantaneous mixing.

\section{Background Fluorescence}

Sampling for background fluorescence is a critical component of the dilution gaging technique. Where background readings exist, adjustments must always be made. Some background is probably not fluorescent but is light reflected from material suspended in the water sample. This problem can be eliminated by allowing the material to settle and by careful handling to avoid resuspension during analysis. It must be stressed that an initial sample just prior to tracer arrival must be obtained to insure that all data can be adjusted to reflect tracer concentrations only.

The problem of background fluorescence, or apparent fluorescence, is potentially serious. In urban runoff it is possible for large variations in background concentrations to occur from storm to storm, as well as during the course of a storm. This is especially true for basins with large differences in land use, which result in varying concentrations of fluorescent or light scattering materials being washed from the land surface by storms of varying intensity, duration, and frequency. In most cases, background-related problems can be minimized by increasing the dye concentration in the injection solution so background is a very small percentage of the sample concentration. In extreme cases an auxillary sampler could be installed upstream from the injection site.

\section{Site Selection and Description}

Two sites were selected in Madison, Wis., to evaluate equipment and methods (fig. 4). Both sites have well-defined, stage-discharge relationships developed during previous urban hydrologic studies.

The Manitou Way storm sewer site drains 0.23 $\mathrm{mi}^{2}$ of gently rolling urban residential area. The gage consists of a 6-in. stilling well located in an $8 \times 10 \times 12 \mathrm{ft}$ cleanout basin. The storm sewer is a 60 -in. concrete pipe. The control is a Palmer Bowlus flume in the invert of the pipe, $20 \mathrm{ft}$ downstream from the gage. The rating is well defined except at extremely high stages. This gage was established in 1970 as part of a lake hydrology project (Oakes and others, 1975) and continued until 1977. The discharge rating from about 0 to $5 \mathrm{ft}^{3} / \mathrm{s}$ was defined by current-meter measurements. The rating for discharges 5.0 to $103 \mathrm{ft}^{3} / \mathrm{s}$ was defined by current meter measurement and supplemented with theoretical rating computations.

The Olbrich Park storm ditch site drains 2.36 $\mathrm{mi}^{2}$ of generally flat urban residential and light industrial area. The gage consists of a manometer. The mixing reach is a straight concrete-lined trapezoidal open channel that extends $1,300 \mathrm{ft}$ upstream from the gage. Upstream from this point the flow is contained in a $5 \times 10.5 \mathrm{ft}$ rectangular underground storm sewer.

The control is a dual culvert about $20 \mathrm{ft}$ downstream from the gage. The manometer orifice is attached to the upstream face of the culvert abutment. This station was established in 1976 as part of a storm-water runoff modeling project (Grant and Goddard, 1979). The rating is defined by current-meter measurements through the range of discharges from 0 to $200 \mathrm{ft}^{3} / \mathrm{s}$, the range recorded during this study.

At the Manitou Way storm-sewer site the injection equipment was located in a catch basin $300 \mathrm{ft}$ upstream from the gage. The tracer was introduced into the center of the flow from the crown of the sewer using a single-point injection. The mixing reach was $300 \mathrm{ft}$ of 60 -in. diameter smooth precast concrete pipe. There was no significant inflow in the reach.

The Olbrich Park storm ditch injection equipment was attached to the headwall of the storm sewer outlet, $1,300 \mathrm{ft}$ upstream from the gage. The 


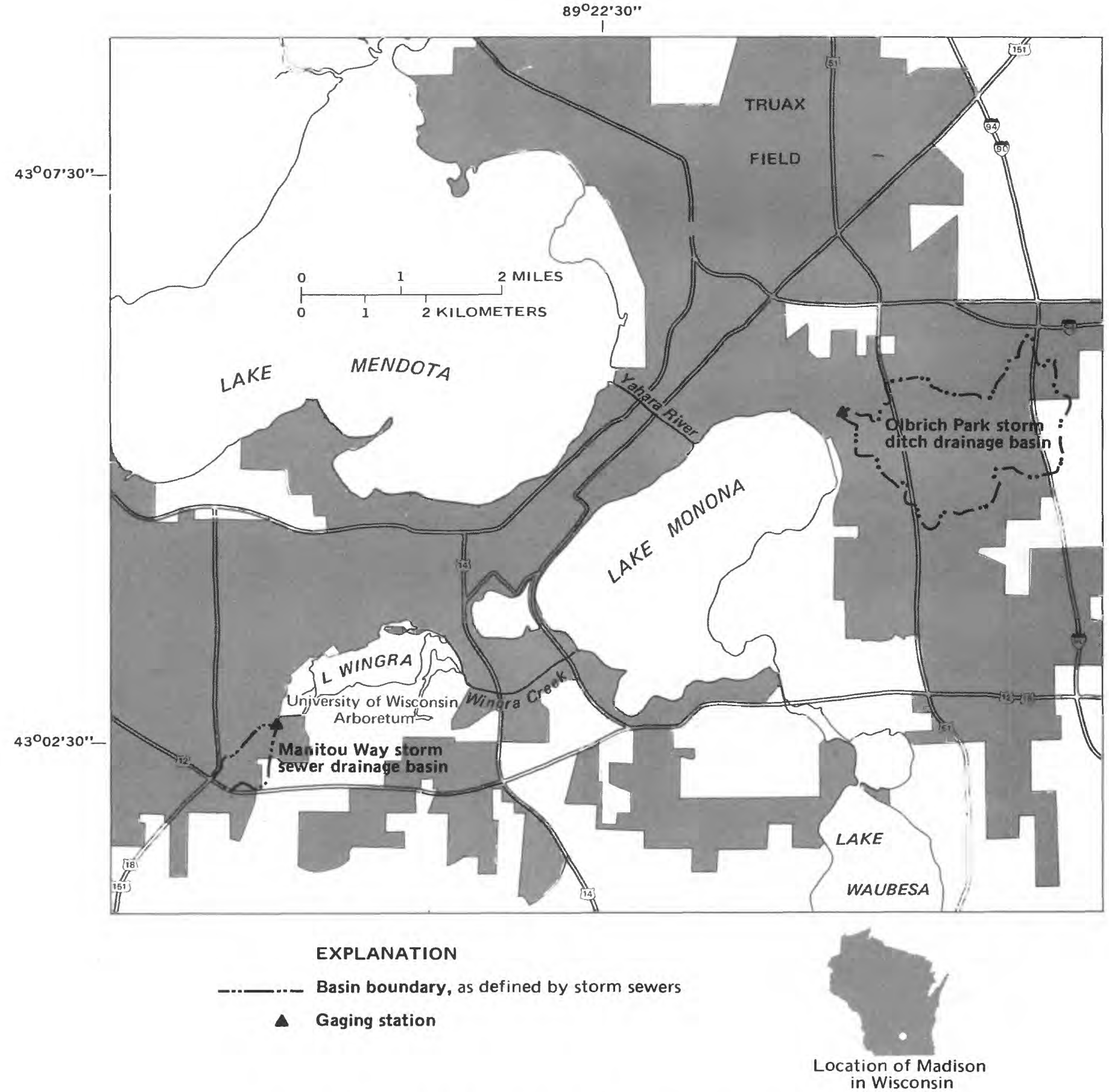

Figure 4. Location of drainage basins and storm-sewer-gaging stations used in study. 
tracer was introduced into the flow from the crown of the outlet. Two injection tubes were attached to the headwall at the quarter points of the flow. The mixing reach is $1,300 \mathrm{ft}$ of open concrete-lined trapezoidal channel. There is no significant tributary inflow in the mixing reach but, as might be expected, small amounts of overland flow enter the channel throughout the entire reach.

To evaluate the degree of adequate mixing at both sites, hand samples were obtained at a minimum of three points in the sampling sections at each site. While these samples showed good mixing, the samples unfortunately were obtained only at discharges at the lower part of the rating curve. Therefore, mixing was not verified for higher discharges.

\section{Equipment}

The dye-injection method must have the following characteristics for measuring unsteady flows: permit a constant flow rate to be maintained, pump enough volume to allow multiple injection when mixing lengths are restricted, be reliable, and be easily maintained.

To provide this versatility, a direct-current, constant-rate peristaltic pump was chosen as the means of dye injection. The pump contains a solid-state, speed-control circuit which allows different rate settings; the unit is powered by a 12-volt deep cycle storage battery. The pump performed well unattended and was found to deliver a stable, constant-rate injection. The pumping rate was checked after each storm and was found to be very stable. The pump used for this study is marketed by Cole Parmer Instrument Company, Chicago, Ill., under the trade name Masterflex DC-powered pump drive Model MF7533-20. The speed range is from 20 to 90 revolutions per minute which yields a flow range from 1.2 to 342 milliliters per minute $(\mathrm{ml} / \mathrm{min})$ by using one of six interchangable pump heads. The pump head chosen for this study had a flow rate from 16 to $77 \mathrm{ml} / \mathrm{min}$. The pump drive is capable of driving two heads of similar capacity for a two-point injection. Additional multiple-injection points can be obtained by using a larger pump head and a manifold-orifice arrangement. The dye reservoir was designed as a mariotte vessel to supply dye at a constant head to the injection pump, and to seal the tracer solution from dirt and evaporation.
The requirements for the automatic water sampler used to collect the diluted dye are: (1) it must be capable of obtaining a sample when flow velocities are high, (2) it must take discrete samples and not allow cross contamination between samples, (3) it can be activated and deactivated remotely, and (4) it will allow individual samples to be coordinated with stage at a given time. The water sampler chosen for this project was the ISCO model 2100 sampler with optional glass sample bottles and a Teflon sampling line. The glass bottles and Teflon line were used to remove any question of dye loss in the sampling system although rhodamine-WT is known (Kilpatrick, written commun., 1982) to have little or no affinity for plastics similar to the kind used in the standard sample bottle and sampling line.

A Rustrak Model 292-4, four-channel event recorder was used to coordinate the time of each dye sample with the appropriate gage height and to record injection pump activity. One channel was used to indicate when the injection pump started and stopped, the second to record the time of each sample, and the third to record the stage at the time of sampling. The fourth channel was not used.

An electrical switching circuit was designed to control the systems. Its main components are two 12 -volt DC relays. The switching circuit controls the automatic water sampler, four-channel event recorder, and the dye-injection pump. These switching circuits were activated by stage. A float switch in the stilling well was used at the Manitou Way storm sewer and a microswitch attached to the manometer was used at the Olbrich Park storm ditch.

\section{Systems Operation}

Data collection is divided into three major categories: pre-event, event, and post-event activities. Pre-event activities included selecting the proper water-dye mixture, injection rate, and sampling interval. The sampling intervals were chosen from estimates of storm duration and rate of discharge change as well as stage recorder punch interval. The system can be programed to sample independently or in conjunction with the stage recorder.

At the Manitou Way site, a 3-minute sampling interval and a 5-minute stage recorder punch inter- 
val was used initially. The sampling interval was changed to operate in conjunction with the stage recorder to improve stage-sample coordination. A sampling and stage recorder punch interval of 5-minutes was also used for the Olbrich Park site.

After the sampling interval was selected, total injection time was computed by multiplying the number of potential samples (24) times the sampling interval.

The volume of dye needed was then computed using the following formula (Cobb and Bailey, written commun., 1965).

$$
\mathrm{V}_{\mathrm{d}}=\mathrm{k} \mathrm{C}_{2} / \mathrm{C}_{\mathrm{d}} \mathrm{QT}
$$

where:

$\mathrm{V}_{\mathrm{d}}=$ volume of dye solution in milliliters, to be added to water in the injection reservoir;

$\mathrm{C}_{\mathrm{d}}=2.38 \times 10^{8}$, the concentration, in micrograms per liter, of rhodamine-WT 20 percent by weight; (1.19 = specific gravity of dye solution);

$\mathrm{C}_{2}=$ concentration of dye, in micrograms per liter, at sampling site (use $10 \mathrm{ppb}$ );

$\mathrm{Q}=$ estimate of maximum stream discharge, in cubic feet per second;

$\mathrm{T}=$ total injection time, in hours; and

$\mathrm{k}=$ the constant of $102 \times 10^{6}$, which is a conversion factor.

The volume of water needed to mix with the dye estimated from equation 2 was calculated from the following formula:

$$
\mathrm{V}_{\mathrm{w}}=\mathrm{qd}^{\mathrm{t}}-\mathrm{V}_{\mathrm{d}}
$$

where:

$\mathrm{V}_{\mathrm{w}}=$ volume of water in milliliters;

$\mathrm{qd}=$ injection rate of dye-water solution, in milliliters per minute; and

$\mathrm{t}=$ total injection time, in minutes.
During a runoff event when a predetermined stage was reached, the switching circuit was activated which, in turn, activated the system as follows. The four-channel event recorder was started. A sample of the flow was taken by the automatic sampler to determine the background fluorescence. This sample as well as subsequent samples were recorded by a tick mark on channel two of the event recorder. The injection pump began dispensing tracer at a constant rate. The start of pumping was recorded on channel one of the event recorder. During the storm, the injection continued at a constant rate. Pump operation was indicated as a solid line on the event recorder. The automatic sampler continued sampling at preselected time intervals. Each stage punch was recorded by a tick mark on channel three of the event recorder. This sequence continued until the stage fell below the predetermined value or the last sample was taken. When either occurred, the sampler and injection pump, along with their respective event recorder channels, were deactivated. Each sample and the elapsed pumping time were thus recorded. The stage channel of the event recorder continued to operate until deactivated by a visitor to the station. By noting the watch time and recorder time, the stage recorder event marks were coordinated with the sampler event marks to assign the proper stage to each sample. Additionally, by computing the elapsed time the pump was on and the volume of dye used, the injection rate was checked.

Post-event procedures at the downstream sampling site include removing sample bottle and recorder tape, inspecting the stage recorder, and preparing for subsequent events.

The switching circuit was designed to allow the event recorder to remain in operation after the event, to record the time of each stage-recorder punch. When the station was visited, the switching circuit was manually deactivated. The watch time and the tape time of the last stage recorder punch was noted on the event tape, as well as the watch time of the last stage recorder event mark. This allowed sample-stage coordination.

Next, the number of water samples taken was noted and compared with the number of sample event marks on the event recorder tape. The samples were capped and labeled before removal from the sampler. The bottles were replaced and the sampler reset to bottle number one. The gage's stage recorder tape was removed to allow samplestage coordination at a later time. 
To avoid dye contamination of the samples and sampling equipment, the injection site was always serviced after the sampling site. Post-event procedures at the injection site included checking the dye injection rate, cleaning the dye tubing with water or methanol, refilling the dye reservoir and checking the voltage of the battery used to supply power to the injection pump.

The samples were then taken to the laboratory for prompt fluorometric analysis. The procedures used for analyses are described by Wilson (1968).

\section{DATA ANALYSIS}

Data were collected during 1981 for 13 storms at the Manitou Way storm sewer. Eleven of the 13 storms provided acceptable data for analysis. Data were not used for one storm because of a malfunction of the water-stage recorder. The second failure was a result of gravel filling the settling basin behind the Palmer Bowlus flume, temporarily destroying the stage-discharge relationship. In both cases the automatic dilution equipment operated properly.

Data were collected for seven storms at the Olbrich Park storm ditch. Data from six of these produced acceptable results. One storm produced unacceptable data because of the failure of a speedcontrol circuit in the injection pump.

\section{Comparison of Discharge by Dilution Gaging with an Established Rating}

Figures 5 through 10 present discharge data from the selected storms. Discharge hydrographs based on the existing ratings are compared to discharge computed by the dilution technique. Included with each figure is a tabular listing of the discharges from the rating curve, dilution measurements, and, the percentage difference between the rating discharge and the values computed by dilution techniques.

Tables 2 and 3 compare peak discharge values measured by dilution to discharge values from the rating curves for each set of data that was analyzed. In addition the percent difference between the rating values and the dilution values are listed. For the Olbrich Park site, the difference between peak discharge data ranged from -12.2 percent to +8.6 percent, with an average difference of -1.4 percent. At the Manitou Way site, the difference ranged from -4.2 percent to +5.4 percent, with an average difference of +0.7 percent.

The discharge data computed by the dye-dilution technique were also plotted on the previously established rating curves for each gaging station. These curves are shown as figures 11 and 12 . As illustrated, the dye-dilution technique provides discharge data in excellent agreement with the established ratings.

\section{Discussion of Methods}

One approach to the measurement of flow is to apply the dilution gaging technique to the measurement of individual storm hydrographs. This would be accomplished by injecting and sampling throughout a single storm allowing each discharge measurement (sample) to represent a point on a hydrograph. This method assumes that all sampling errors can be accounted for, a sampling interval can be chosen so samples span the entire runoff event, hydrograph breaks can be adequately defined, and that the tracer solution chosen for the injection will allow proper tracer concentrations for laboratory analysis throughout the full range of discharge expected.

The excellent agreement shown when the dyedilution measurements are plotted on the previously defined stage-discharge ratings for both the Olbrich Park and the Manitou Way sites (figs. 11-12) suggests that a more practical way to apply the technique would be to use the discharges obtained by the dilution method at several stages from one or more storms to develop a conventional stage-discharge rating. This allows for errors caused by rapid stage or discharge changes, variations in background fluorescence, and faulty laboratory analysis to be identified readily and eliminated from the rating analysis. In addition, temporary physical changes to the control, even if not recognized as such, can be excluded from the rating. This method allows erroneous values to be eliminated from the analysis without necessarily determining their origin. This method also permits flexibility in selecting dye injection volumes and sampling intervals that match areas of concern on the rating curve.

Acceptable results were obtained from this study although little known direct information on 
the effect of unsteady flow was collected. 1n all cases dilution gaging overestimated discharge at the start of all storm hydrographs and in most cases on the rising limbs. During rapidly changing discharges it is extremely difficult to coordinate stage readings with the tracer samples. There is, in most cases, 20 to 30 seconds lag between the stage recorder punch and the completed sampling cycle. This could account for some discrepancies during rapidly changing stages.

Background fluorescence was not apparent at the Manitou Way site, whereas, small variations were noted from storm to storm and in some cases from before to after storms at the Olbrich site.

Dye loss by organic processes is also possible but was not apparent during this study. Also dye losses on sampling equipment and cross contamination of samples are potentially serious problems with automating dilution gaging. By using automatic water samplers with glass sample bottles, Teflon sampling lines, and sample line conditioning (backflushing), these problems can be minimized.

\section{SUMMARY AND CONCLUSIONS}

The data collected at both sites produced acceptable results. Generally dilution discharge measurements were within 5 to 10 percent of the existing current-meter based ratings with larger differences occurring at the start and on the rising limbs of most hydrographs. Mixing lengths were adequate and dye loss was not found to be a problem. Stagesample coordination difficulties were found at the Manitou Way site where rapidly changing stages were common, but the problem was minimized by changing sampling modes. Originally the sampler was programed to activate independently of the stage recorder but was reprogramed to activate with the stage recorder punch cycle.

Automatic dilution gaging is a workable method of obtaining discharge information when conventional methods cannot be used. To obtain acceptable results requires: care in selecting and evaluating mixing conditions, monitoring background fluoresence, and good field and laboratory techniques.
In addition, a thorough knowledge of fluorometric procedures is needed if fluorescent tracers are used. The tracer injection rate is a critical element. Reliable constant-rate injection equipment is essential. Coordination of samples with the proper stage reading is also very important.

\section{SELECTED REFERENCES}

Gilman, K., 1975, Application of a residence time model to dilution gauging, with particular reference to the problem of changing discharge: Hydrological Sciences Bulletin, No. XX, v. 4. 1977, Dilution gauging on the recession limb: 1. Constant rate injection method: $\mathrm{Hy}-$ drological Sciences Bulletin, No. XXII, v. 3.

Grant, R. S., and Goddard, Gerald, 1979, Urban storm-runoff modeling--Madison, Wisconsin: U.S. Geological Survey Water-Resources Investigations Open-File Report 79-1273, 29 p.

Hubbard, E. F., Kilpatrick, F. A., Martens, L. A., and Wilson, J. F., Jr., 1982, Measurement of time of travel and dispersion in streams by dye tracing: U.S. Geological Survey Techniques of Water-Resources Investigations, Book 3 Chapter A9, $44 \mathrm{p}$.

Kilpatrick, F. A., 1968, Flow calibration by dyedilution measurement: Civil Engineering, v. 38, February 1968, p. 74-76.

Oakes, E. L., Hendrickson, G. E., and Zuehls, E.E., 1975, Hydrology of the Lake Wingra basin, Dane County, Wisconsin: U.S. Geological Survey Water-Resources Investigations 17-75, $31 \mathrm{p}$.

Scott, C. H., Norman, V. W., and Fields, F. K., 1969, Reduction of fluorescence of two tracer dyes by contact with a fine sediment: U.S. Geological Survey Professional Paper 650-B, p. B154-B168.

Wilson, J. F., Jr., 1968, Fluorometric procedures for dye tracing: U.S. Geological Survey Techniques of Water-Resources 1nvestigations, Book 3, Chapter A13, 31 p.

Yotsukura, Nobuhiro, and Cobb, E. D., 1972, Transverse diffusion of solutes in natural streams: U.S. Geological Survey Professional Paper 582-C, 19 p. 


$\begin{array}{cccc}\begin{array}{c}\text { Time } \\ \text { (in hours) }\end{array} & \begin{array}{c}\text { Discharge from } \\ \text { rating curve } \\ \left(\mathbf{f t}^{3} / \mathbf{s}\right)\end{array} & \begin{array}{c}\text { Discharge as measured } \\ \text { by dye dilution } \\ \left(\mathrm{ft}^{3} / \mathbf{s}\right)\end{array} & \begin{array}{c}\text { Percent } \\ \text { difference }\end{array} \\ 1735 & 36 & - & - \\ 40 & 143 & 162 & 13.3 \\ 45 & 177 & 173 & -2.3 \\ 50 & 180 & 180 & .0 \\ 55 & 160 & 149 & -6.9 \\ 1800 & 114 & 114 & .0 \\ 05 & 72.5 & 73.1 & .8 \\ 10 & 50.4 & 46.9 & -6.9 \\ 15 & 35.8 & 33.9 & -5.3\end{array}$

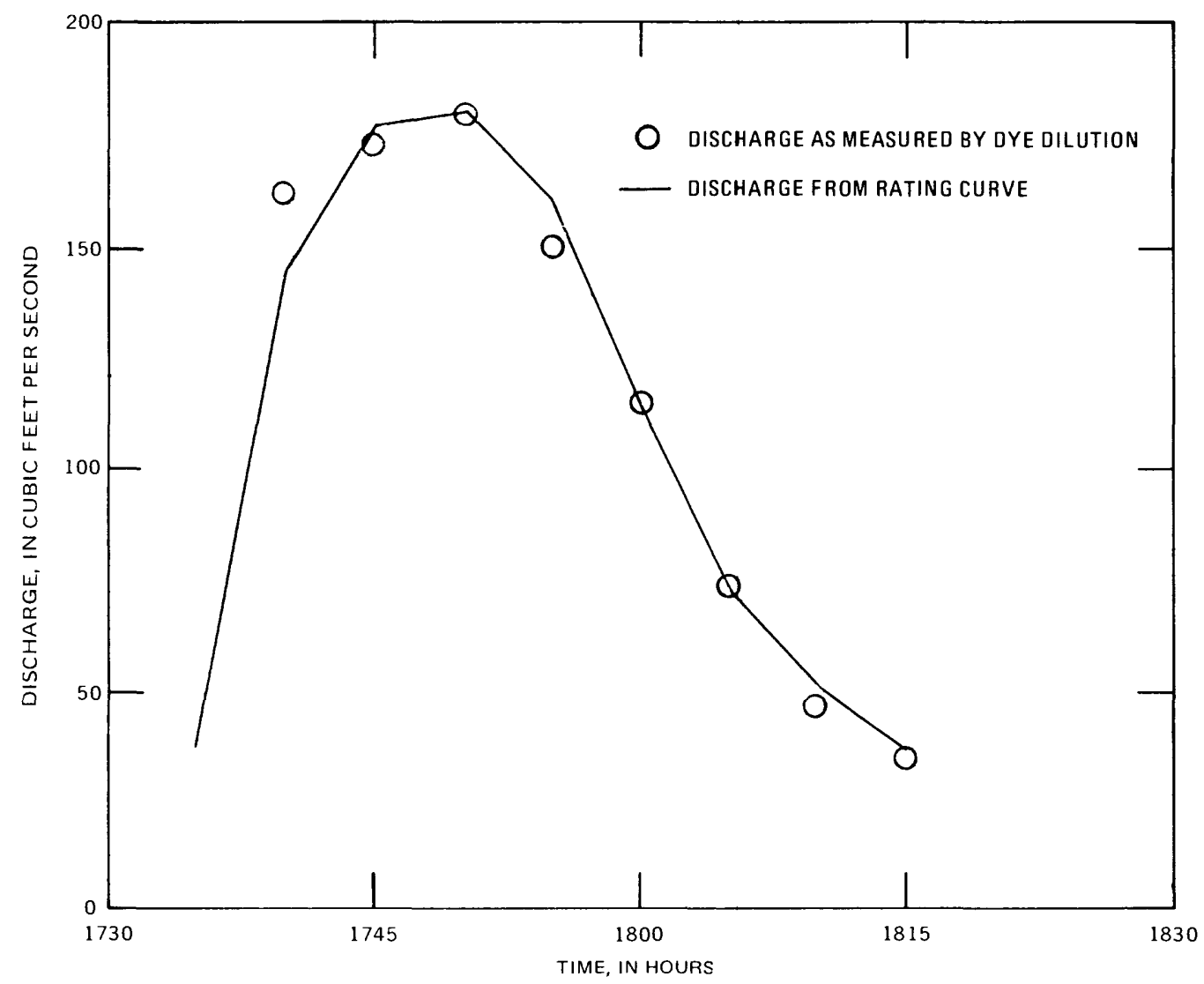

Figure 5. Hydrograph of Olbrich Park storm ditch for July 12, 1981 showing comparison of discharge data. 


$\begin{array}{cccc}\begin{array}{c}\text { Time } \\ \text { (in hours) }\end{array} & \begin{array}{c}\text { Discharge from } \\ \text { rating curve } \\ \left(\mathrm{ft}^{3} / \mathrm{s}\right)\end{array} & \begin{array}{c}\text { Discharge as measured } \\ \text { by dye dilution } \\ \left(\mathrm{ft}^{3} / \mathrm{s}\right)\end{array} & \begin{array}{c}\text { Percent } \\ \text { difference }\end{array} \\ 1600 & & & \\ 05 & 58.4 & 235 & - \\ 10 & 180 & 182 & -2.4 \\ 15 & 209 & 204 & -2.0 \\ 20 & 203 & 199 & 13.8 \\ 25 & 159 & 181 & -8.9 \\ 30 & 123 & 112 & \\ 35 & & & 4.8 \\ 40 & 84.6 & 88.7 & 0 \\ 45 & 61.4 & 61.4 & 2.0 \\ 50 & 51.0 & 52.0 & 3.2 \\ 55 & 57.2 & 59.0 & -52.8 \\ & 63.3 & 29.9 & -59.4 \\ 1700 & 79.6 & 32.3 & -65.2 \\ 05 & & 33.7 & -0.0 \\ 10 & 96.9 & 127 & 3.9 \\ 15 & 105 & 113 & 3.6 \\ 20 & 114 & 107 & -7.0 \\ 25 & 103 & 95.3 & -6.3 \\ 30 & 92.0 & 84.9 & 5.0 \\ 35 & 91.2 & 83.1 & 1.9 \\ 40 & 88.7 & 84.0 & -5.4 \\ 45 & 80.0 & 80.5 & -6.0 \\ 50 & 79.0 & 68.1 & \\ 55 & 72.0 & 63.9 & \\ & 68.0 & 58.8 & \end{array}$

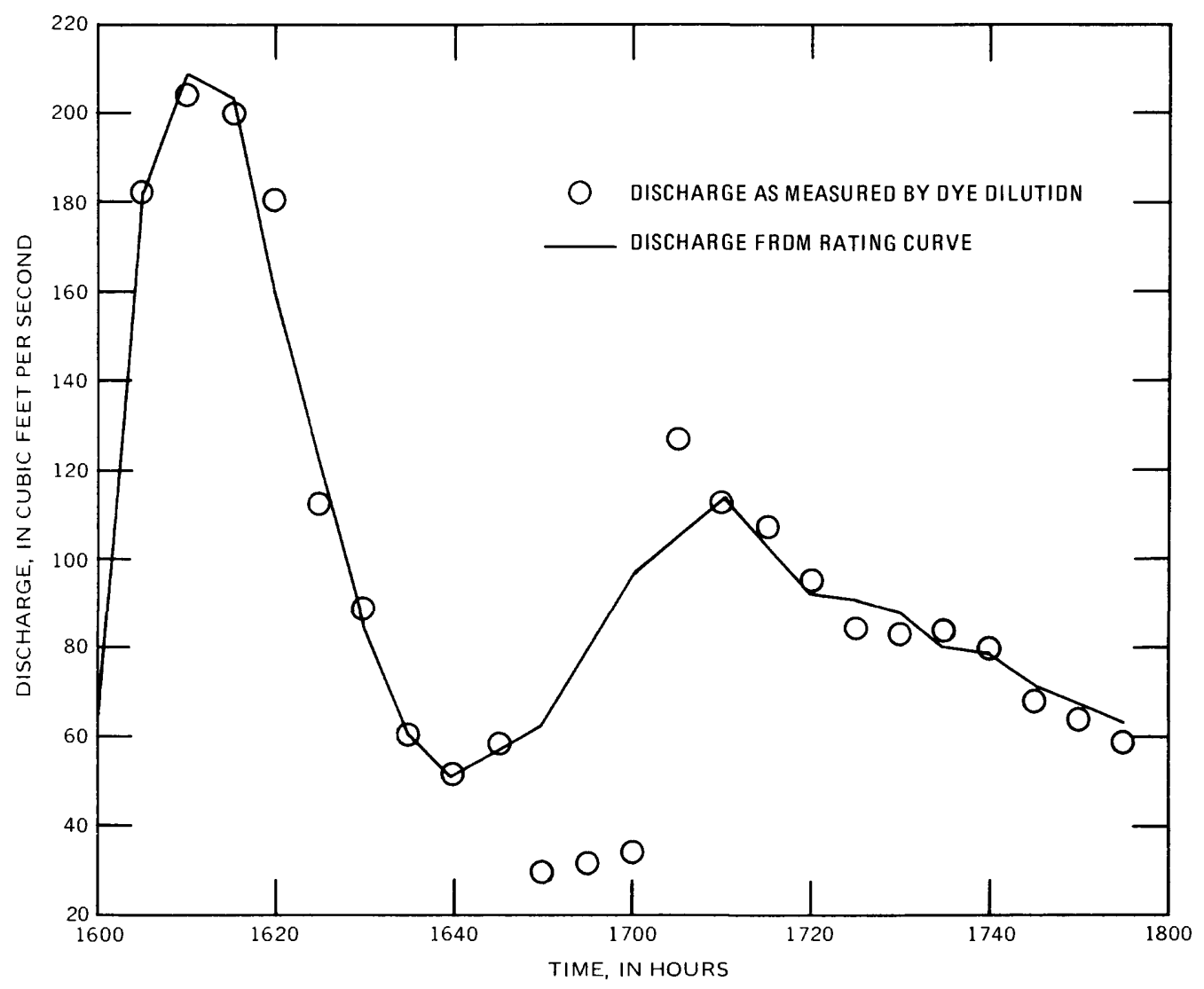

Figure 6. Hydrograph of Olbrich Park storm ditch for August 14, 1981, showing comparison of discharge data. 


$\begin{array}{cccc}\begin{array}{c}\text { Time } \\ \text { (in hours) }\end{array} & \begin{array}{c}\text { Discharge from } \\ \text { rating curve } \\ (\mathbf{f t} \mathbf{3} / \mathbf{s})\end{array} & \begin{array}{c}\text { Discharge as measured } \\ \text { by dye dilution } \\ (\mathbf{f t} 3 / \mathbf{s})\end{array} & \begin{array}{c}\text { Percent } \\ \text { difference }\end{array} \\ 2300 & & & \\ 05 & 51 & 56.5 & 10.8 \\ 10 & 90.3 & 86.2 & -4.5 \\ 15 & 145 & 142 & -2.1 \\ 20 & 158 & 166 & 5.1 \\ 25 & 187 & 203 & 8.6 \\ & 207 & 230 & 11.1 \\ 30 & & 227 & 8.6 \\ 35 & 209 & 200 & 5.3 \\ 40 & 190 & 181 & 8.4 \\ 45 & 167 & 154 & 2.7 \\ 50 & 150 & 142 & 2.9 \\ 55 & 138 & 144 & 4.4 \\ & 138 & & -2.5 \\ 2400 & & 135 & 0 \\ 05 & 133 & 127 & -6.2 \\ 10 & 130 & 118 & 2.9 \\ 15 & 118 & 105 & -2.1 \\ 20 & 112 & 107 & -2.1 \\ 25 & 104 & 98.9 & -0.3 \\ & 101 & 94.1 & 0.7 \\ 30 & & 95.8 & -2.6 \\ 35 & 96.1 & 91.8 & -8.5 \\ 40 & 966.1 & 87.6 & \end{array}$

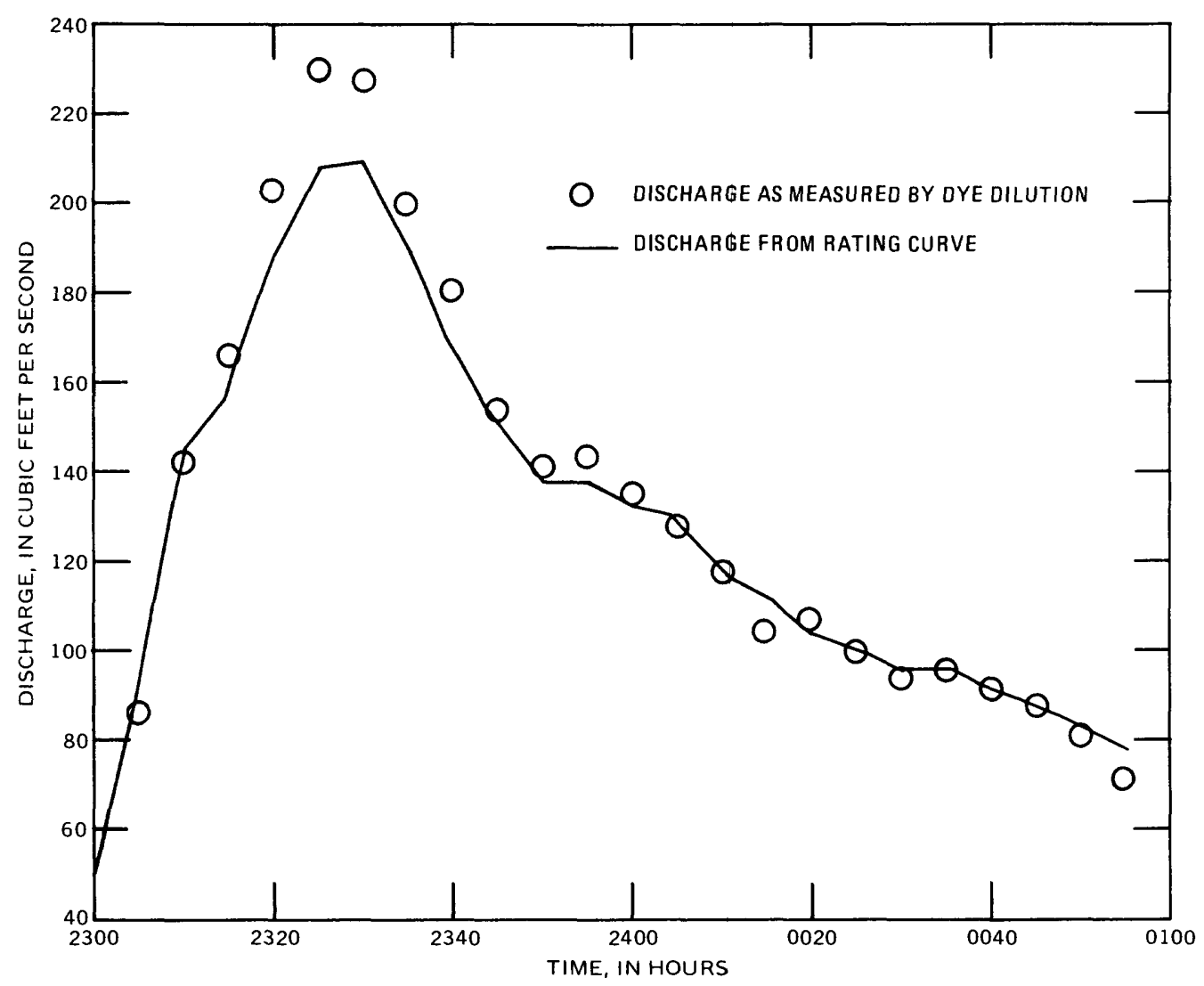

Figure 7. Hydrograph of Olbrich Park storm ditch for August 31-September 1, 1981, showing comparison of discharge data. 


$\begin{array}{cccc}\begin{array}{c}\text { Time } \\ \text { (in hours) }\end{array} & \begin{array}{c}\text { Discharge from } \\ \text { rating curve } \\ \left(\mathrm{ft}^{3} / \mathbf{s}\right)\end{array} & \begin{array}{c}\text { Discharge as measured } \\ \text { by dye dilution } \\ \left(\mathrm{ft}^{3} / \mathbf{s}\right)\end{array} & \text { Percent } \\ 0047 & 3.10 & 4.50 & \\ 50 & 3.50 & 3.69 & 45.2 \\ 53 & 3.60 & 3.73 & 5.4 \\ 56 & 3.71 & 3.72 & 3.6 \\ 59 & 3.50 & 3.61 & .3 \\ & & 3.1 \\ 0102 & 3.30 & 3.30 & 0 \\ 05 & 2.83 & 3.01 & 6.4 \\ 08 & 2.65 & 2.71 & 2.3 \\ 11 & 2.47 & 2.46 & -.4 \\ 14 & 2.30 & 2.30 & -3.0 \\ 17 & 2.30 & 2.23 & -1.8 \\ 20 & 2.22 & 2.18 & -1.9 \\ 23 & 2.14 & 2.10 & -1.9 \\ 26 & 2.14 & 2.10 & -5.4 \\ 29 & 2.22 & 2.10 & -11.8 \\ 32 & 2.38 & 2.10 & -18.0 \\ 35 & 2.56 & 2.10 & -3.8 \\ 38 & 2.92 & 2.81 & \end{array}$

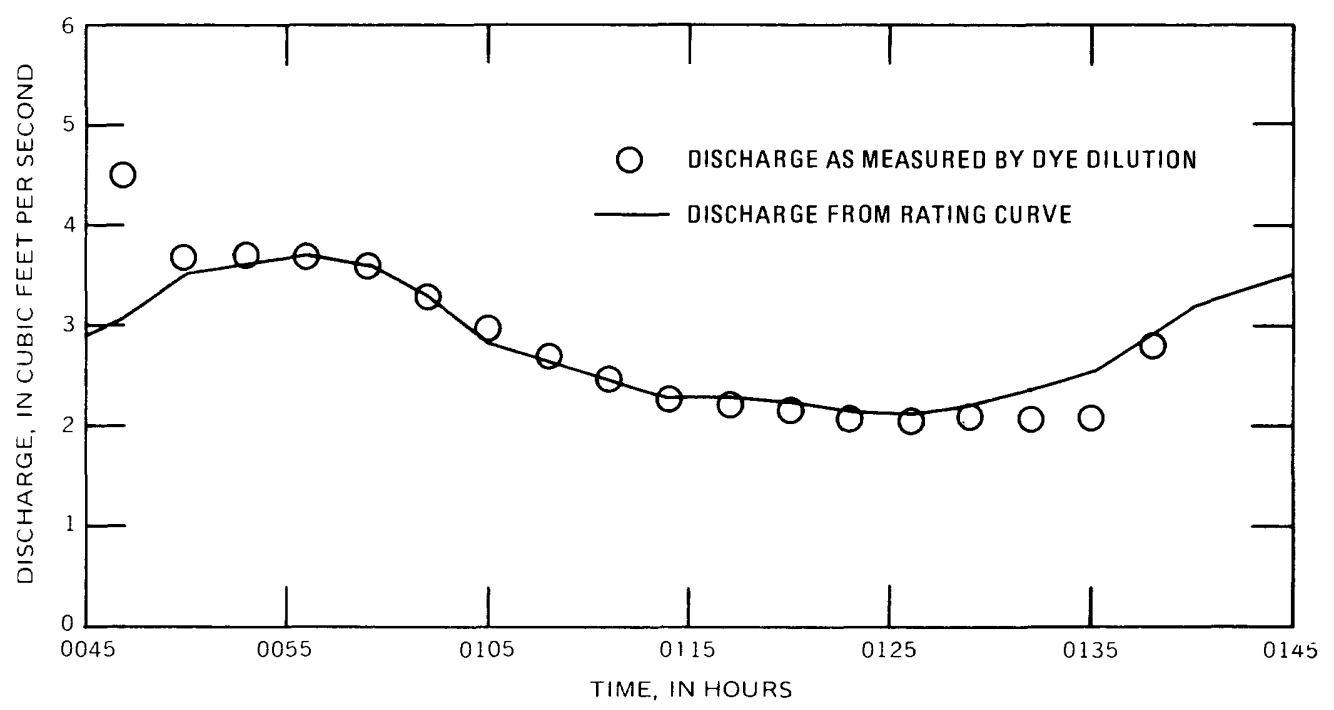

Figure 8. Hydrograph of Manitou Way storm sewer for June 13, 1981, showing comparison of discharge data. 


$\begin{array}{cccc}\begin{array}{c}\text { Time } \\ \text { (in hours) }\end{array} & \begin{array}{c}\text { Discharge from } \\ \text { rating curve } \\ \left(\mathrm{ft}^{3} / \mathbf{s}\right)\end{array} & \begin{array}{c}\text { Discharge as measured } \\ \text { by dye dilution } \\ \left(\mathrm{ft}^{3} / \mathbf{s}\right)\end{array} & \begin{array}{c}\text { Percent } \\ \text { difference }\end{array} \\ 1419 & 2.90 & - & - \\ 20 & 4.20 & 4.05 & -3.6 \\ 23 & 5.60 & 5.61 & .2 \\ 26 & 6.60 & 6.67 & 1.1 \\ 29 & 6.90 & 6.97 & 1.0 \\ 32 & & & \\ 35 & 6.60 & 6.88 & 4.2 \\ 38 & 6.10 & 6.08 & -3 \\ 41 & 5.20 & 5.45 & 4.8 \\ 44 & 4.80 & 4.67 & -2.7 \\ 47 & 4.50 & 4.15 & -7.8 \\ 50 & 5.60 & 5.21 & -7.0 \\ 53 & 7.40 & 6.52 & -11.9 \\ 56 & 8.00 & 7.15 & -10.6 \\ 59 & 8.40 & 7.30 & -13.1 \\ & 8.60 & 8.79 & 2.2 \\ 1502 & & & -2.2 \\ 05 & 6.90 & 6.75 & 3.6 \\ 08 & 4.70 & 4.87 & 2.4 \\ 11 & 3.40 & 3.48 & 5.6 \\ 14 & 2.50 & 2.64 & 6.8\end{array}$

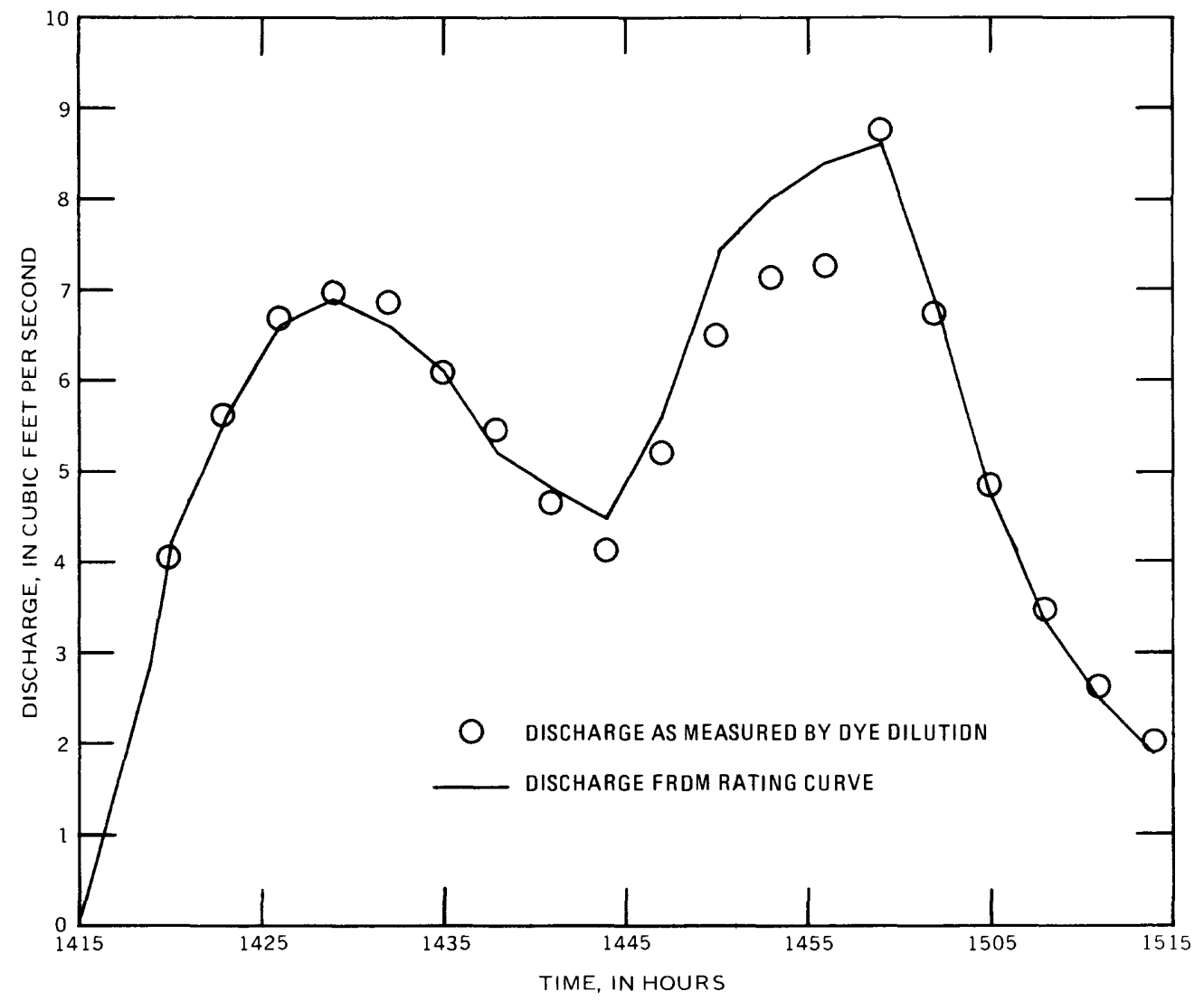

Figure 9. Hydrograph of Manitou Way storm sewer for July 11, 1981, showing comparison of discharge data. 


$\begin{array}{rccc}\begin{array}{c}\text { Time } \\ \text { (in hours) }\end{array} & \begin{array}{c}\text { Discharge from } \\ \text { rating curve } \\ \left(\mathrm{ft}^{3} / \mathrm{s}\right)\end{array} & \begin{array}{c}\text { Discharge as measured } \\ \text { by dye dilution } \\ \left(\mathrm{ft}^{3} / \mathrm{s}\right)\end{array} & \begin{array}{c}\text { Percent } \\ \text { difference }\end{array} \\ 1139 & 4.80 & 6.73 & \\ 42 & 7.00 & 7.45 & 40.2 \\ 45 & 9.05 & 9.07 & 6.4 \\ 48 & 9.50 & 9.90 & .2 \\ 51 & 9.86 & 9.93 & 4.2 \\ 54 & 9.53 & 9.21 & .7 \\ 57 & 9.00 & 9.28 & -3.4 \\ & & & 3.1 \\ 1200 & 8.14 & 8.03 & -1.4 \\ 03 & 7.13 & 7.07 & -.8 \\ 06 & 6.45 & 6.32 & -2.0 \\ 09 & 5.79 & 5.79 & .0 \\ 12 & 5.30 & 5.22 & -1.5 \\ 15 & 4.80 & 4.81 & .2 \\ 18 & 5.06 & 4.91 & -3.0 \\ 21 & 5.42 & 5.60 & 3.3 \\ 24 & 6.04 & 6.13 & 1.5 \\ 27 & 6.04 & 6.18 & 2.3 \\ 30 & & & -2.4 \\ 33 & 5.79 & 5.65 & .5 \\ 36 & 4.81 & 4.88 & .2 \\ 39 & 4.04 & 4.05 & 2.1 \\ 42 & 3.40 & 3.47 & -2.1 \\ 45 & 3.40 & 3.33 & 2.1\end{array}$

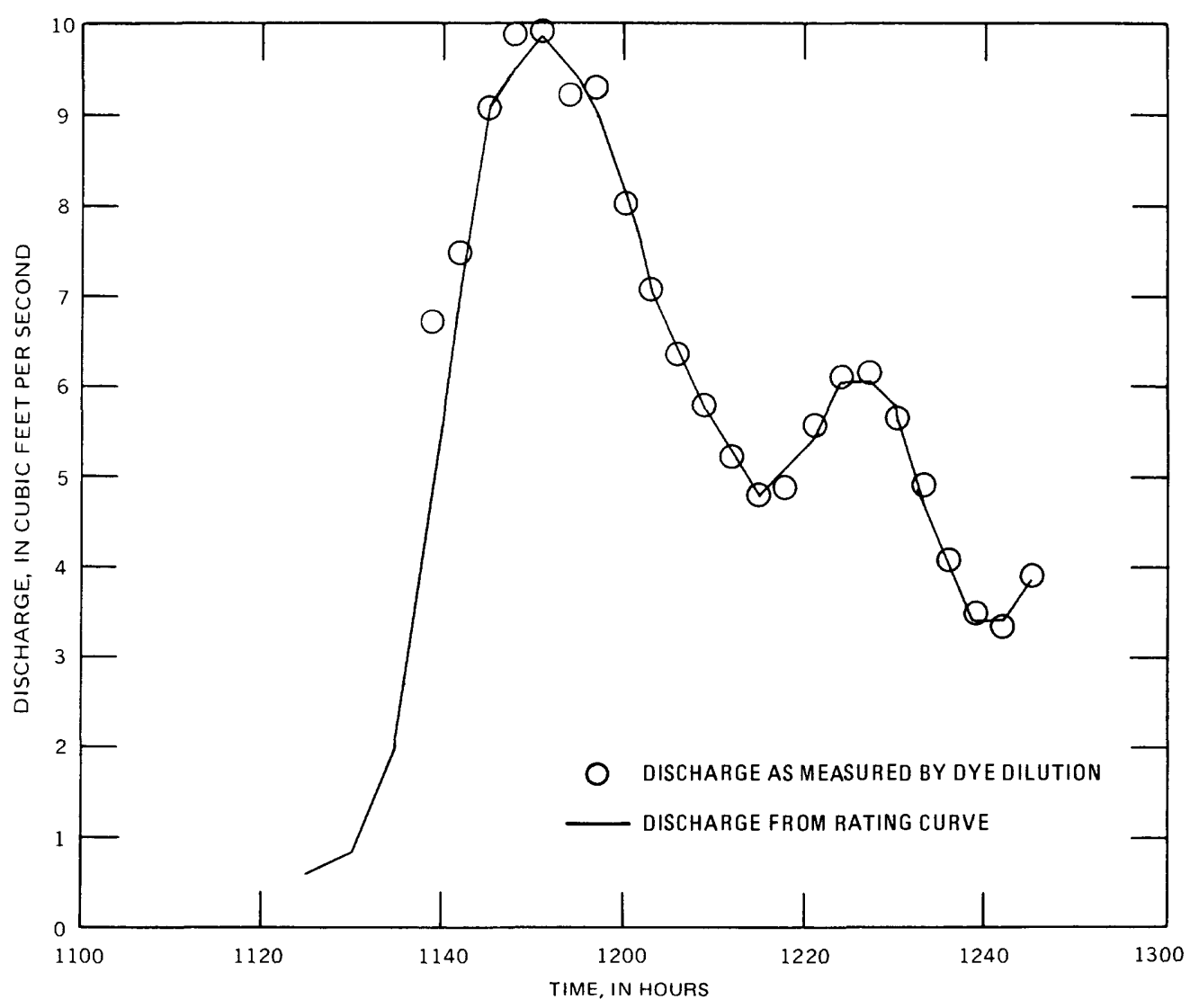

Figure 10. Hydrograph of Manitou Way storm sewer for September 7, 1981, showing comparison of discharge data. 


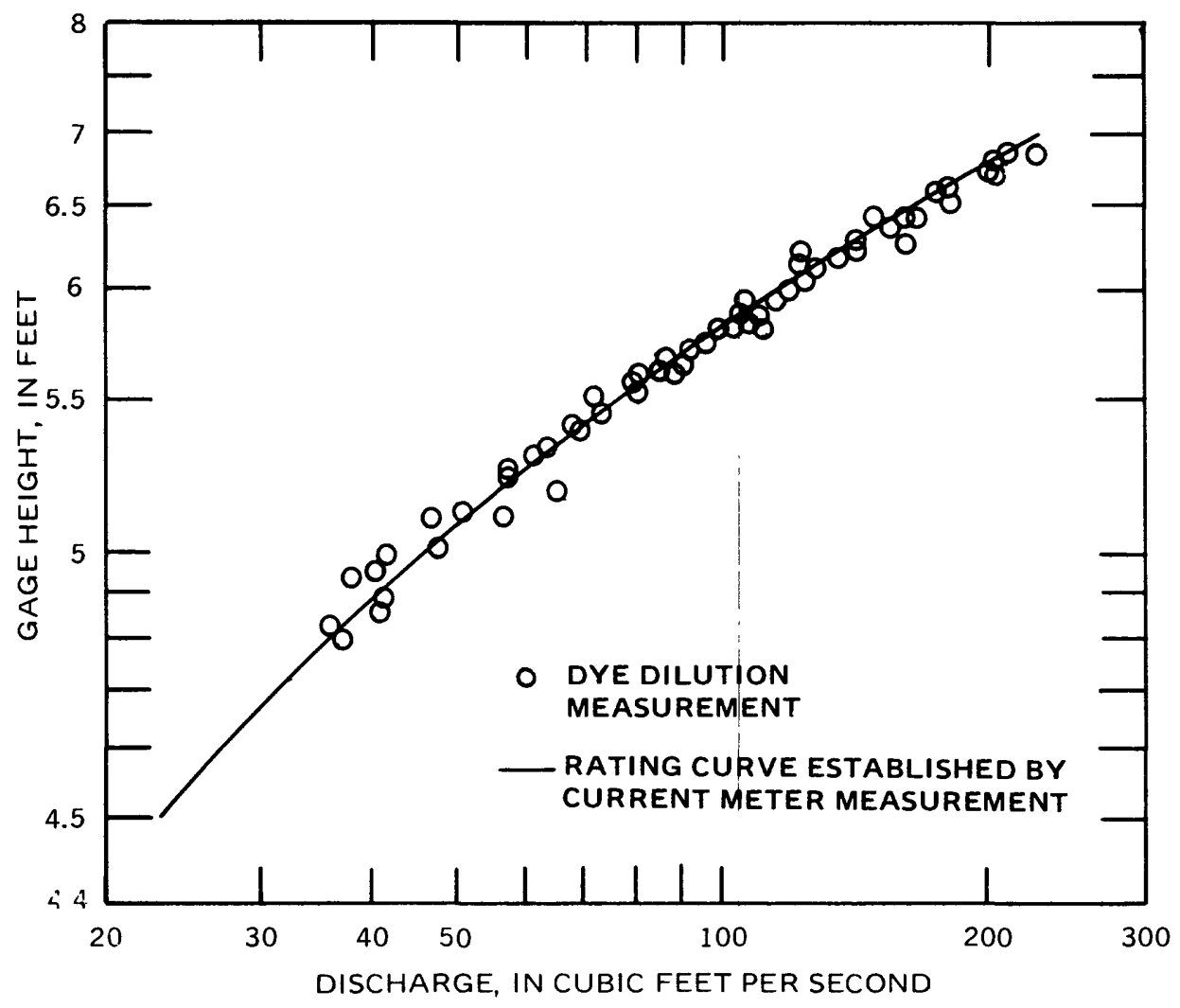

Figure 11. Comparison of dye-dilution measurements with rating curve for Olbrich Park storm ditch.

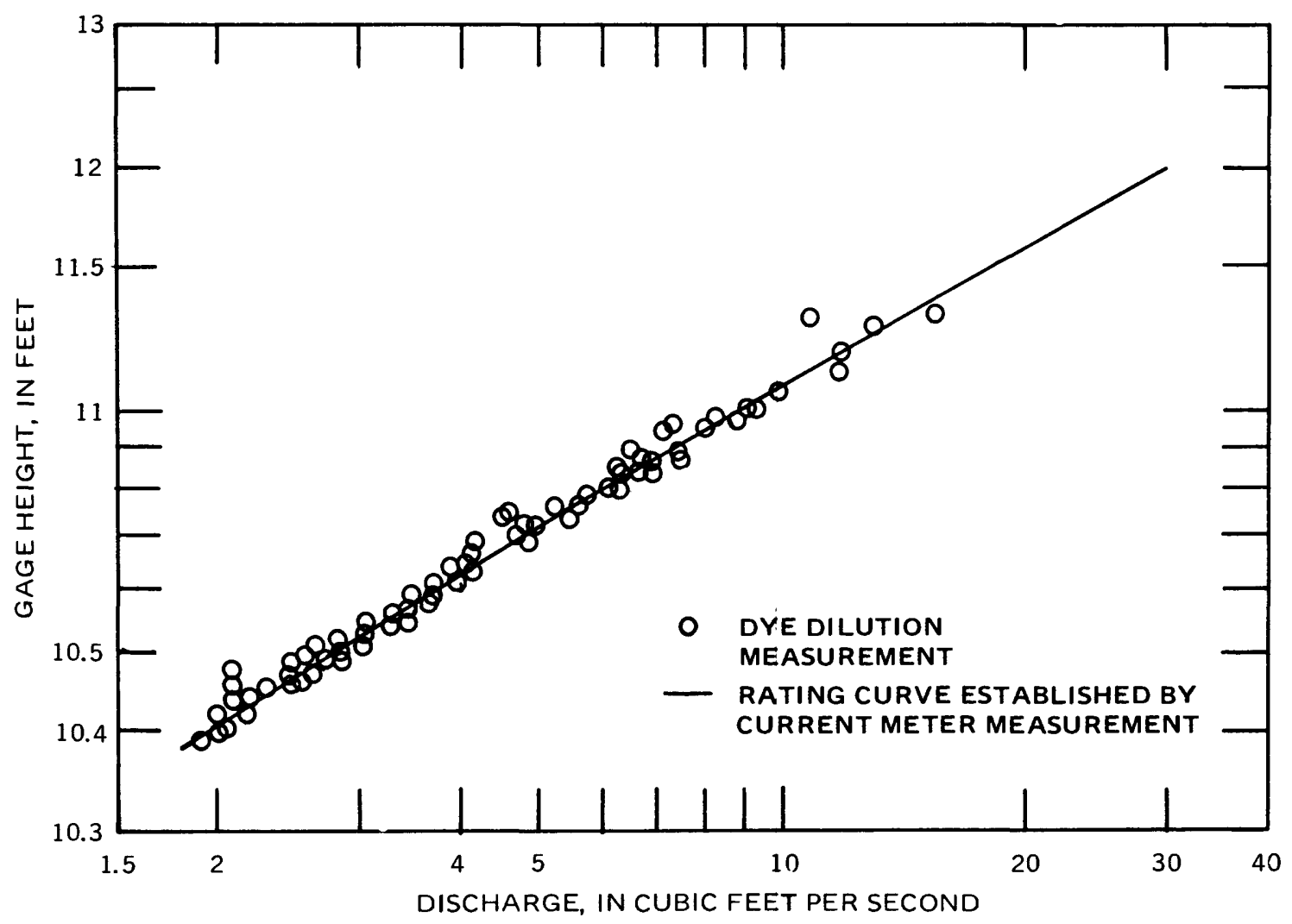

Figure 12. Comparison of dye-dilution measurements with rating curve for Manitou Way storm sewer. 
Table 2. Comparison of peak discharge from dilution gaging to discharge from rating curve, Olbrich Park.

$\begin{array}{lccc}\text { Date } & \begin{array}{c}\text { Discharge from } \\ \text { rating curve } \\ \left(\mathrm{ft}^{3} / \mathrm{s}\right)\end{array} & \begin{array}{c}\text { Peak discharge } \\ \text { from dye dilution* } \\ \left(\mathrm{ft}^{3} / \mathrm{s}\right)\end{array} & \begin{array}{c}\text { Percent } \\ \text { difference }\end{array} \\ 1981 & 180 & 180 & 0.0 \\ \text { July } 12 & 139 & 122 & -12.2 \\ \text { July } 13 & 42.8 & 40.4 & -5.6 \\ \text { July } 13 & 105 & 108 & 2.9 \\ \text { July 20 } & 209 & 204 & -2.4 \\ \text { Aug. 14 } & 209 & 227 & 8.6 \\ \text { Aug. 31 } & & & -1.4 \\ \text { Average } & & & \\ \text { * Maximum discharge measured by dye dilution. }\end{array}$

Table 3. Comparison of peak discharge from dilution gaging to discharge from rating curve, Manitou Way.

\begin{tabular}{|c|c|c|}
\hline Date & $\begin{array}{l}\text { Discharge from } \\
\text { rating curve } \\
\left(\mathrm{ft}^{3} / \mathrm{s}\right)\end{array}$ & $\begin{array}{c}\text { Peak discharge } \\
\text { from dye dilution* } \\
\left(\mathrm{ft}^{3} / \mathrm{s}\right)\end{array}$ \\
\hline
\end{tabular}

1981

$\begin{array}{lccc}\text { June } 13 & 3.71 & 3.72 & 0.3 \\ \text { July } 11 & 8.60 & 8.79 & 2.2 \\ \text { Aug. 2 } & 3.20 & 3.30 & 3.1 \\ \text { Aug. } 14 & 4.04 & 3.87 & -4.2 \\ \text { Aug. } 14 & 8.44 & 8.70 & 3.1 \\ \text { Aug. } 26 & 4.04 & 4.12 & 2.0 \\ \text { Aug. 29 } & 13.7 & 13.1 & -4.4 \\ \text { Aug. 29 } & 14.7 & 15.5 & 5.4 \\ \text { Sept. 7 } & 9.86 & 9.93 & 0.7 \\ \text { Sept. 16 } & 3.60 & 3.60 & 0.0 \\ \text { Sept. 21 } & 4.70 & 4.69 & -0.2 \\ \text { Average } & & & +0.7\end{array}$

*Maximum discharge measured by dye dilution. 